\title{
QUEEN'S
UNIVERSITY
BELFAST
}

\section{Stay clean: direct steam exposure to manage biofouling risks}

Joyce, P. W. S., Cuthbert, R. N., Kregting, L., Crane, K., Vong, G., Cunningham, E., Dick, J. T. A., \& Coughlan, N. E. (2019). Stay clean: direct steam exposure to manage biofouling risks. Marine Pollution Bulletin, 142, 465469. https://doi.org/10.1016/j.marpolbul.2019.04.011

Published in:

Marine Pollution Bulletin

Document Version:

Peer reviewed version

Queen's University Belfast - Research Portal:

Link to publication record in Queen's University Belfast Research Portal

\section{Publisher rights}

Copyright 2019 Elsevier.

This manuscript is distributed under a Creative Commons Attribution-NonCommercial-NoDerivs License

(https://creativecommons.org/licenses/by-nc-nd/4.0/), which permits distribution and reproduction for non-commercial purposes, provided the author and source are cited.

\section{General rights}

Copyright for the publications made accessible via the Queen's University Belfast Research Portal is retained by the author(s) and / or other copyright owners and it is a condition of accessing these publications that users recognise and abide by the legal requirements associated with these rights.

\section{Take down policy}

The Research Portal is Queen's institutional repository that provides access to Queen's research output. Every effort has been made to ensure that content in the Research Portal does not infringe any person's rights, or applicable UK laws. If you discover content in the Research Portal that you believe breaches copyright or violates any law, please contact openaccess@qub.ac.uk. 
$11{ }^{1}$ School of Natural and Built Environment, Queen's University Belfast, Belfast, BT9 5BN, UK

12

13 'Queen's Marine Laboratory, Queen's University Belfast, 12-13 The Strand, Portaferry, BT22 1PF, 14 Northern Ireland, UK

15

$16{ }^{3}$ Institute for Global Food Security, School of Biological Sciences, Queen's University Belfast, 17 Medical Biology Centre, 97 Lisburn Road, Belfast, BT9 7BL, Northern Ireland, UK

18

19

20

*Corresponding author: neil.coughlan.zoology@gmail.com

$21 \uparrow$ These authors contributed equally to this work.

22 


\section{Abstract}

39 Biofouling by marine organisms can result in a variety of negative environmental and economic 40 consequences, with decontamination procedures remaining problematic, costly and labour-intensive.

41 Here, we examined the efficacy of direct steam exposure to induce mortality of selected biofouling 42 species: Mytilus edulis; Magallana gigas; Semibalanus balanoides; Fucus vesiculosus; and an Ulva 43 sp. Total mortality occurred at 60-sec of steam exposure for M. edulis and juvenile M. gigas, at 30-sec 44 for $S$. balanoides, while 300-sec was required for adult M. gigas. Application of steam reduced the 45 biomass of $F$. vesiculosus and significantly reduced Ulva sp. biomass, with complete degradation being 46 observed for Ulva sp. following 120-sec of exposure. Accordingly, it appears that steam exposure can 47 cause mortality of biofouling organisms through thermal shock. Although preliminary, our novel and promising results suggest that steam applications could potentially be used to decontaminate niche

49 50 51 52 53 54 55 56 58 59 60 61 62 63 64 65 66 67 68 69 70 


\section{Introduction}

The natural colonisation of submerged surfaces by adhering organisms, i.e. biofouling, can result in substantial economic and environmental impacts for a variety of marine-based industries, such as shipping, desalination/purification and aquaculture (Schultz 2007; Nurioglu et al. 2015). In particular, biofouling presents a range of design and operational challenges for marine renewable energy devices, and is considered a priority research topic for this emerging industry (Loxton et al. 2017). Moreover, as artificial coastal infrastructure such as docks and floating pontoons can provide suitable habitats for biofouling species, commercial harbours and recreational marinas may act as source habitats for general nuisance species as well as damaging invaders, thus facilitating their further spread (Ferrario et al. 2017; Marić et al. 2017; Iacarella et al. 2019). Biofouling organisms and biofilm layers may also harbour and facilitate the further spread of damaging pathogenic microorganisms (Kent 1992; Douglas-Helders et al. 2003; Drake et al. 2005).

Biofouling by invasive alien species (IAS) can adversely impact marine biodiversity, ecosystem functioning, human health and marine-based industries, e.g. fishing and tourism (Bax et al. 2003; Molnar et al. 2008; Lovell \& Drake 2009). Once established at a new location, the complete eradication of aquatic invaders is often unfeasible, while on-going population suppression is costly (Piria et al. 2017; Coughlan et al. 2018b). The adherence of IAS to equipment, watercraft and moveable infrastructure, especially within niche areas that are difficult to inspect or decontaminate such as sea chests, chain lockers, pipework, intake grates, and fishing nets (Sylvester \& MacIsaac 2010; Moser et al. 2017; de Castro et al. 2018), represents an important pathway for the translocation of damaging marine invaders, which continue to spread at an unprecedented rate worldwide (Ricciardi et al. 2016; Seebens et al. 2016; Iacarella et al. 2019).

To date, mitigation of biofouling has largely been managed through the use of preventative biocidal (toxic) paints, chemical cleaning agents and physical decontamination methods, such as encapsulation, brushing, scraping, high-pressure washing, and hand removal (Hopkins et al. 2016; Growcott et al. 2017; Silva et al. 2019). More recently, following the high-profile international ban on the use of tributyltin compounds in biocides, there has been increased focus on the use of environmentally-friendly non-toxic preventative coatings (Silva et al. 2019). However, as discussed by Hopkins et al. (2016), despite meaningful advances in prevention of biofouling, not all surfaces are amenable to antifouling paints, e.g. fishing equipment, aquaculture infrastructure, mooring lines, and drilling rigs. Accordingly, numerous other decontamination methods have been proposed as suitable alternatives, including exposure to desiccation (Hopkins et al. 2016), low salinity (de Castro et al. 2018), ultraviolet light (Titus \& Ryskiewich 1994), acid or alkaline soaking treatments (Rolheiser et al. 2012) and heated water (Piola \& Hopkins 2012). However, the efficacy of these treatments is often unknown (Hopkins et al. 2016; Growcott et al. 2017). Many removal techniques also rely on visual 
inspection to confirm the absence of biofouling organisms following decontamination treatments, however, visual inspection of some sections of equipment may not be possible, and decontamination methods alone (e.g. desiccation, brushing, scraping, high-pressure washing, hand-removal) will not necessarily result in complete propagule removal or mortality of adhering organisms (Rothlisberger et al. 2010; Coughlan et al. 2018a). Accordingly, innovative, cost-effective and environmentallyfriendly, yet highly efficacious techniques, are urgently required (Growcott et al. 2017; Crane et al. 2019; Coughlan et al. 2019).

Notably, the thermal application of steam treatments has been suggested as one such method, and may be a particularly beneficial addition to out of water dock-side decontamination procedures, especially for niche areas such as internal surfaces of pipework (Jones \& Little 1990; Growcott et al. 2017; Cahill et al. 2019). However, the physiological tolerances of biofouling organisms, i.e. their susceptibility to thermal shock, to the innovative and novel approach of steam decontamination remains poorly studied.

In this study, we thus examined the efficacy of brief out of water direct steam exposure to induce mortality of selected common biofouling species, including two bivalve molluscs, Mytilus edulis and invasive Magallana gigas (formerly Crassostrea gigas), one barnacle species, Semibalanus balanoides, and two alga species, Fucus vesiculosus and an Ulva sp. We hypothesised that direct steam exposure will induce substantial, if not complete, mortality of the targeted biofouling species, dependent on exposure time.

\section{Methods}

\subsection{Specimen collection and maintenance}

All organisms were collected in Northern Ireland (NI) from a variety of locations (Table 1), and transported in source water to the Queen's Marine Laboratory (QML), Portaferry, NI. Specimens were maintained in outdoor flow-through seawater tanks at $\sim 12{ }^{\circ} \mathrm{C}$, for a period of $48-72 \mathrm{hrs}$ prior to commencement of the experiments.

\subsection{Experimental steam exposure}

Each species was independently exposed to steam treatments. Experimental groups included: ten adult $M$. edulis (total shell length: 35.27 - $44.95 \mathrm{~mm}$; shell length per group, mean $\pm \mathrm{SE}: 40 \pm 0.2$ $\mathrm{mm})$; ten juvenile $M$. gigas $(14.9-15 \mathrm{~mm})$; a $5 \mathrm{~cm}^{2}$ area with $\geq 80 \%$ cover of $S$. balanoides $(71.5 \pm$ 2.6 individuals); subsamples of $F$. vesiculosus $(60.5 \pm 0.3 \mathrm{~g})$; and subsamples of Ulva sp. (35.3 \pm 0.3 g). Due to their relatively large size, adult specimens of $M$. gigas $(90.94-146.61 \mathrm{~mm}$ : $110.8 \pm 3.3$ $\mathrm{mm}$ ) were each steamed individually. Experimental groups were placed on a flat plastic board and 

were directly exposed to a continuous jet of steam $\left(\geq 100^{\circ} \mathrm{C} ; 350 \mathrm{kPa}\right.$; Karcher ${ }^{\circledR} \mathrm{SC} 3 \mathrm{Steam}$ Cleaner) at a distance of $2-3 \mathrm{~cm}$ from the spout of the device for: 10, 30, 60, 120 or 300-sec (Table 1). All treatments were replicated in triplicate for each species examined, except adult M. gigas, which were replicated six times. The jet of steam was manoeuvred along the entire upwards facing area of each experimental group, i.e. specimen or group of specimens, for the duration of the assigned exposure time by repeatedly moving the jet of steam in an oscillating manner. Control groups were allowed to air dry for the maximum 300-sec treatment period. Following steam exposure, specimens were allowed to cool for a 15-min period and were then placed in outdoor flow-through seawater tanks at $\sim 12{ }^{\circ} \mathrm{C}$. A $24 \mathrm{hr}$ recovery period was allowed for M. edulis, M. gigas and S. balanoides, after which mortality was assessed. Specimens were considered dead if they were gaping, or if they offered no resistance to being teased apart with tweezers and did not reclose. Changes in mass following a 12 or 5 day recover period were recorded for $F$. vesiculosus and the Ulva sp., respectively. Percentage tissue degradation of the Ulva sp. was also visually recorded in relation to the surface area.

\subsection{Data analyses}

Data analyses were performed using R v3.4.4 (R Core Development Team 2018). Differences in mean bivalve shell lengths according to steam treatment groups were analysed using one-way Kruskal-Wallis rank sum tests. Mortality of M. edulis, M. gigas and S. balanoides was examined with respect to steam exposure time using generalised linear models assuming binomial error distributions. Bias-reduced penalised-likelihood logistic regression was implemented where perfect separation occurred (Firth 1993). Likelihood ratio tests between nested models were used to infer significance levels according to steam treatment. Differences in F. vesiculosus and Ulva sp. weights (natural-log transformed) before and after steam treatments were examined using analysis of variance, given residuals were normally distributed (Shapiro-Wilk test, $P>0.05$ ) and homoscedastic (Bartlett's test, $P>0.05)$. Ulva sp. tissue degradation was additionally analysed with respect to steam treatment using beta regression (Cribari-Neto and Zeileis 2010), following appropriate transformations (Smithson and Verkuilen 2006). Where necessary, Tukey post-hoc tests were used to deduce pairwise comparisons among steam treatment levels.

\section{Results}

\subsection{Mytilus edulis}

Shell lengths of bivalves did not differ significantly according to stream treatment groups $\left(\chi^{2}\right.$ $=3.99, d f=5, P>0.05)$. Steam exposure significantly increased mortality of mussels Mytilus edulis $\left(\chi^{2}=192.58, d f=5, P<0.001\right.$; Fig. 1A). Survival of mussels was $100 \%$ in control groups, and total 
mortality was evidenced at steam exposures of 60 -sec and longer. Post-hoc comparisons between treatment groups are shown on Fig. 1A.

\subsection{Juvenile Magallana gigas}

For juvenile $M$. gigas, exposure to steam also caused a significant increase in mortality $\left(\chi^{2}=\right.$ 135.83, $d f=5, P<0.001$; Fig. 1B). Survival of juvenile $M$. gigas in control groups was $100 \%$ and total mortality was observed following steam exposures of $60-\mathrm{sec}$ and longer. Post-hoc comparisons between treatment groups are shown on Fig. 1B.

\subsection{Adult Magallana gigas}

Shell lengths of bivalves did not differ significantly according to stream treatment groups $\left(\chi^{2}\right.$ $=7.61, d f=3, P>0.05)$. Although adult $M$. gigas mortality was significantly increased following exposure to steam $\left(\chi^{2}=24.94, d f=3, P<0.001\right)$, with total mortality observed after 300 -sec exposures, no significant pairwise difference occurred between treatment groups $(P>0.05$; Fig. 1C).

\subsection{Semibalanus balanoides}

Steam treatment significantly increased mortality of barnacles $\left(\chi^{2}=856.73, d f=4, P<0.001\right.$; Fig. 1D). Whilst control survival exceeded $90 \%$ in all replicates, total mortality was observed in barnacles treated with steam for 30-sec or longer. Post-hoc comparisons between treatment groups are shown on Fig. 1D.

\subsection{Fucus vesiculosus}

Changes to weights of the examined brown fucoid alga were not significantly influenced by treatment with steam $\left(F_{4}, 10=3.26, P>0.05\right.$; Fig. $\left.2 \mathrm{~A}\right)$. However, whilst weight differences among control, 10, 30 and 60-sec treatment groups were similar, weights following 120-sec steam exposures were reduced substantially and consistently.

\subsection{Ulva sp.}

Overall, weights of the filamentous green alga were significantly reduced after steam exposure $\left(F_{4,10}=9.25, P<0.01\right.$; Fig. 2B). Post-hoc comparisons between treatment groups are shown on Fig. 2B.

Steam treatment also significantly increased visually-scaled degradation of the Ulva sp. $\left(\chi^{2}=\right.$ 45.41, $d f=4, P<0.001$; Fig. 2C). Here, all steam exposure times degraded the filamentous green alga significantly more than controls (all $P<0.001$ ), and up to complete degradation was observed following 120-sec treatments. Post-hoc comparisons between treatment groups are shown on Fig. 2C. 
The direct application of steam caused complete mortality for all examined biofouling invertebrates within exposure times of 30-60-sec, except adult M. gigas, which required 300-sec of steam exposure for total morality to be achieved. For the macroalgae, following steam exposure both species displayed a reduction in relative biomass, with Ulva sp. being completely degraded following 120 -sec of steam exposure. Accordingly, when taken together, these results indicate that the rapid decontamination of equipment and niche areas could be achieved with brief out of water steam exposure. Although it appears that longer exposure times will be needed to kill larger adult organisms, reasonably frequent applications will likely prevent the development of adult life stages and reduce the detrimental impacts of biofouling species. Interestingly, although an overall trend of decreased relative biomass was observed for $F$. vesiculosus, some specimens exposed to short treatment times of $\leq 60$-sec also displayed increased biomass, an interesting response that warrants further investigation. Equally, F. vesiculosus presented the largest surface area of all examined organisms (PWSJ and NEC per. obs.), and therefore would not have experienced the same intensity of steam per unit area of its external surfaces as the other examined organisms. Yet our results for macroalgae are indicative only, and a more thorough assessment is required. For example, warm-water acclimated organism may experience a reduced impact of thermal shock. For an improved assessment, longer steam exposure times, warm-water acclimated organisms, and an extended recovery period should be used to thoroughly assess the effect of steam exposure on $F$. vesiculosus. In addition, the examination in-water steam delivery systems and their efficacy is required. Overall, however, the application of rapid steam treatments could potentially be used to prevent the establishment and spread of nuisance organisms and damaging invaders.

The application of heat treatments in the form of heated water has previously been successfully used to exterminate damaging biofouling organisms, prevent the establishment of complex fouling assemblages, and decontaminate niche areas (Inglis et al. 2012; Piola \& Hopkins 2012; Cahill et al. 2019). Yet, the application of steam could possibly be more efficacious than hot water treatments in certain scenarios, as additional thermal energy in the form of latent heat will be released with the condensation of steam into water (see $1^{\text {st }}$ Law Thermodynamics). In essence, whilst remaining at a constant temperature, this physical state change from a gas to a liquid will transfer a greater amount of thermal energy to target organisms. Also, heated water can be impractical or cost-prohibitive when applied at a large-scale, particularly when the water temperature needs to be consistently maintained within a set range to achieve uniform mortality of target species (Inglis et al. 2012; Piola \& Hopkins 2012; Growcott et al. 2017). But the economic cost of steam treatments will need to be clarified. In addition, the post-treatment release of large volumes of hot water can have ecological consequences, 
including thermal shock-induced mortality of non-target organisms, and the dispersion of biofouling organisms that have survived treatment exposure. Although in-water steam treatments will have similar operational concerns, such incidents of thermal pollution and species dispersion are potentially more avoidable with the use of steam during dry dock-side treatment, which will mostly dissipate into the surrounding air and is not likely to flush living organisms through pipework unless highly pressurised. Equally, although the use of broad-spectrum aquatic disinfectants has been proposed as a rapid method for achieving enhanced biosecurity (Rolheiser 2012; Cuthbert et al. 2018; 2019), the release of large volumes of chemical solutions following treatment could have similarly prohibitive environmental consequences.

Although steam treatments used here will likely kill adhering organisms through intense thermal shock, steam will not necessarily remove the residual biomass, unless delivered under pressure. That being said, groups of steam-treated $S$. balanoides appeared to detach from stone surfaces much more readily than non-treated specimens when handled for assessment by experimental operators (PWSJ and NEC pers. obs.). Despite this, dead organisms will eventually decompose, while the direct application of pressurised jets (e.g. through a lance like device) of steam may prove effective for both in-water and dry dock-side targeted removal of biofouling organisms, particularly when synergistically combined with additional cleaning methods, such as hand removal, brushing or scraping. Ensuring total mortality of adhering invasive species prior to removal attempts, could be especially beneficial for reducing opportunities for further invader spread. Installation of steam cleaning devices at points of entry (e.g. marinas, harbours and boat ramps) may facilitate utilisation of this simple and environmentally-friendly, but highly efficacious biosecurity protocol (Crane et al. 2019). These steam decontamination facilities could mimic the design of car-wash stations (Coughlan et al. 2019), and could potentially be designed for self-service or operated by a trained attendant (Crane et al. 2019).

Importantly, however, once the required intensity of steam to efficaciously kill target organisms has been deciphered, visual inspection of surfaces will no longer be necessarily required. For example, within niche areas such as the internal surface of pipework, and complex structures like sea chests, temperature sensors could be used to ensure an adequate duration of steam exposure to cause complete mortality of any biofouling organisms. Essentially, steam generators could be used to inject steam into pipework and other niche areas (Growcott et al. 2017), to facilitate the improved decontamination of large and more structurally complex equipment at high pressures and temperatures, e.g., 10-12 Bar; $\geq 180{ }^{\circ} \mathrm{C}$ (Crane et al. 2019). Under such conditions the efficaciousness of steam treatments would likely be further enhanced, as the target organisms would be exposed to increased levels of thermal energy, retained as latent heat within the pressurised and hotter steam treatments. However, the development of operational treatments for internal niches will require further assessment, especially in relation to heat distribution, and risk of damage to vessel components and existing anti-foul coatings. In particular, further research to assess the effects of steam applications on the integrity of antifouling 
coatings, fibreglass and epoxy resin surfaces of hulls, niche areas and equipment is also required. Although our novel series of experiments represent a realistic and promising starting-point, an improved understanding of the physiological tolerances of biofouling organisms to steam exposure is required. In particular, our experiments require up-scaling to higher densities of organisms, complex fouling assemblages, differential life stages, the assessment of impacts to non-target organisms and water quality parameters, and testing under realistic in situ scenarios.

\section{Acknowledgments}

PWSJ and RNC both acknowledge support from Department for the Economy, Northern Ireland. KC is supported through contributions from Queen's University Belfast, the University of Windsor, McGill University and Waterways Ireland. EMC acknowledges support from Department for Agriculture, Environment, and Rural Affairs, Northern Ireland. JTAD and NEC are supported by the Irish Environmental Protection Agency research grant 2015-NC-MS-4. We thank our two anonymous reviewers for helpful comments.

\section{Author contributions}

PWSJ and NEC proposed the study; PWSJ and NEC designed the experiment; PWSJ, NEC and GYWV conducted the experiment; RNC and NEC performed data analysis; all authors contributed to writing the manuscript, which was led by NEC.

\section{References}

Bax N, Williamson A, Aguero M, Gonzalez E, Geeves W. 2003. Marine invasive alien species: a threat to global biodiversity. Marine Policy 27: 313-23.

Cahill P, Tait L, Floerl O, Bates T, Growcott A, Georgiades E. 2019. A portable thermal system for reactive treatment of biofouled internal pipework on recreational vessels. Marine Pollution Bulletin 139: 65-73.

Coughlan NE, Cuthbert RN, Dickey JWE, Crane K, Caffrey JM, Lucy FE, Davis E, Dick JTA. 2019. Better biosecurity: spread-prevention of the invasive Asian clam, Corbicula fluminea (Müller, 1774). Management of Biological Invasion 10: 111-126.

Coughlan NE, Cuthbert RN, Kelly TC, Jansen MAK. 2018a. Parched plants: survival and viability of invasive aquatic macrophytes following exposure to various desiccation regimes. Aquatic Botany 150: 9-15. 
319

Coughlan NE, Walsh DA, Caffrey JM, Davis E, Lucy FE, Cuthbert RN, Dick JTA. 2018b. Cold as Ice: a novel eradication and control method for invasive Asian clam, Corbicula fluminea, using pelleted dry ice. Management of Biological Invasions. 9: 463-474.

Cuthbert RN, Coughlan NE, Crane K, Caffrey JM, MacIsaac HJ, Dick JTA. 2018. A dip or a dab: assessing the efficacy of Virasure ${ }^{\circledR}$ Aquatic disinfectant to reduce secondary spread of the invasive curly waterweed Lagarosiphon major. Management Biological Invasion 9: DOI: 10.3391/mbi.2018.9.3.08.

Cuthbert RN, Crane K, Dick JTA, Caffrey JM, MacIsaac HJ, Coughlan NE. 2019. Die Hard: impact of aquatic disinfectants on the survival and viability of invasive Elodea nuttallii, Aquatic Botany 154: 11-17.

Crane K, Cuthbert RN, Dick JTA, Kregting L, MacIsaac HJ, Coughlan NE. 2019. Full steam ahead: direct steam exposure to inhibit spread of invasive aquatic macrophytes. Biological Invasions. 8: $259-265$.

Cribari-Neto F, Zeileis A (2010) Beta regression in R. Journal of Statistical Softwware 34: 1-24.

de Castro MCT, Vance T, Yunnie ALE, Fileman TW, Hall-Spencer JM. 2018. Low salinity as a biosecurity tool for minimizing biofouling on ship sea chests. Ocean Sci. 14: 661-667.

Douglas-Helders GM, Tan C, Carson J, Nowak BF. 2003. Effects of copper-based antifouling treatment on the presence of Neoparamoeba pemaquidensis on nets and gills of reared Atlantic salmon (Salmo salar). Aquaculture 221: 13-22.

Drake LA, Meyer A E, Forsberg RL, Baier RE, Doblin MA, Heinemann S, ... Dobbs FC. 2005. Potential invasion of microorganisms and pathogens via 'interior hull fouling': Biofilms inside ballast water tanks. Biological Invasions 7: 969-982.

Ferrario J, Caronni S, Occhipinti-Ambrogi A, Marchini A. 2017. Role of commercial harbours and recreational marinas in the spread of non-indigenous fouling species, Biofouling 33: 651-660.

Firth D (1993) Bias Reduction of Maximum Likelihood Estimates. Biometrika 80: 27-38. 
Growcott A, Kluza D, Georgiades E. 2017. Review: In-water systems to reactively manage biofouling in sea chests and internal pipework. Marine Technology Society Journal 51: 89 -104.

Hopkins GA, Prince M, Cahill PL, Fletcher LM, Atalah J. 2016. Desiccation as a mitigation tool to manage biofouling risks: trials on temperate taxa to elucidate factors influencing mortality rates, Biofouling 32:1, 1-11,

Iacarella, JC, Davidson IC, Dunham A. 2019. Biotic exchange from movement of 'static' maritime structures. Biological Invasions. https://doi.org/10.1007/s10530-018-1888-8

Inglis GJ, Floerl O, Woods C. 2012. Scenarios of Vessel Biofouling Risk and Their Management. An Evaluation of Options. Prepared for the Ministry of Agriculture and Forestry, New Zealand. 126 pp. https://www.mpi.govt.nz/document-vault/4029.

Jones JM, Little B. 1990. USS PRINCETON (CG59): microbiologically influenced corrosion (MIC) and macrofouling status of seawater piping systems. Naval Surface Warfare Center Dahlgren, VA.

(http://www.dtic.mil/cgi-bin/ GetTRDoc?AD=ADA231251\&Location=U2\&doc=GetTRDoc.pdf -Accessed 28/12/2018).

Kent ML. 1992. Diseases of seawater netpen-reared salmonid fishes in the Pacific Northwest. Canadian Special Publication of Fisheries and Aquatic Sciences 116, 76.

Lovell SJ, Drake LA. 2009. Tiny stowaways: analyzing the economic benefits of a U.S. Environmental Protection Agency permit regulating ballast water discharges. Environ Manage 43:546-555

Loxton J, Macleod AK, Nall CR, McCollin T, Machado I, Simas T, Vance T, Kenny C, Want A, Miller RG. 2017. Setting an agenda for biofouling research for the marine renewable energy industry. International Journal of Marine Energy 19: 292-303

Marić M. Ferrario J. Agnese Marchini A. Occhipinti-Ambrogi A. Minchin D. 2017. Rapid assessment of marine non-indigenous species on mooring lines of leisure craft: new records in Croatia (eastern Adriatic Sea). Marine Biodiversity 47: 949-956

Molnar JL, Gamboa RL, Revenga C, Spalding MD. 2008. Assessing the global threat of invasive species to marine biodiversity. Frontiers in Ecology and the Environment 6: 485-492 
407

Moser CS, Wier TP, First MR, Grant JF, Riley SC, Robbins-Wamsley SH, ... Drake LA. 2017. Quantifying the extent of niche areas in the global fleet of commercial ships: The potential for "super hot spots" of biofouling. Biological Invasions 19, 1745-1759.

Nurioglu AG, Esteves ACC, de With G. 2015. Non-toxic, non-biocide-release antifouling coatings based on molecular structure design for marine applications. J. Mater. Chem. B 3: 6547-6570.

Piola R, Hopkins G. 2012. Thermal treatment as a method to control transfers of invasive biofouling species via vessel sea chests. Marine Pollution Bulletin 64:1620-30.

Piria M, Copp GH, Dick JTA, Duplić A, Groom Q, Jelić D, Lucy FE, Roy HE, Sarat E, Simonović P, Tomljanović T, Tricarico E, Weinlander M, Adámek Z, Bedolfe S, Coughlan NE, Davis E, Dobrzycka-Krahel A, Grgić Z, Kırankaya ŞG, Ekmekçi FG, Lajtner J, Lukas JAY, Koutsikos N, Mennen GJ, Mitić B, Pastorino P, Ruokonen TJ, Skóra ME, Smith ERC, Šprem N, Tarkan AS, Treer T, Vardakas L, Vehanen T, Vilizzi L, Zanella D, Caffrey JM. 2017. Tackling invasive alien species in Europe II: threats and opportunities until 2020. Management of Biological Invasions 8: 273-286.

R Core Development Team (2017) A language and environment for statistical computing. Vienna, Austria.

Ricciardi A. 2016. Tracking marine alien species by ship movements. Proc Natl Acad Sci 113: 54705471

Rolheiser KC, Dunham A, Switzer SE, Pearce CM, Therriault TW. 2012. Assessment of chemical treatments for controlling Didemnum vexillum, other biofouling, and predatory sea stars in Pacific oyster aquaculture. Aquaculture 364: 53-60.

Rothlisberger JD, Chadderton WL, McNulty J, Lodge DM. 2010. Aquatic invasive species transport via trailered boats: what is being moved, who is moving it, and what can be done. Fisheries 35 : $121-132$.

Schultz MP. 2007. Effects of coating roughness and biofouling on ship resistance and powering. Biofouling 23, 331-341.

Seebens H, Schwartz N, Schupp PJ, Blasius B. 2016. Predicting the spread of marine species introduced by global shipping. Proc Natl Acad Sci 113:5646-5651 
58

Silva ER, Ferreira O, Ramalho PA, Azevedo NF, Bayón R, Igartua A, Bordado JC, Calhorda MJ. 2019. Eco-friendly non-biocide-release coatings for marine biofouling prevention. Science of the Total Environment 650: 2499-2511.

Smithson M, Verkuilen JA (2006) Better lemon squeezer? Maximum-likelihood regression with betadistributed dependent variables. Psychological Methods 11: 54-71.

Sylvester F, MacIsaac HJ. 2010. Is vessel hull fouling an invasion threat to the Great Lakes? Diversity \& Distributions $16,132-143$.

Titus JM, Ryskiewich BS. 1994. U.S. Patent No. 5,322,569, US Patent and Trademark Office, Washington, D.C.

Figure 1: Mean percentage mortality ( $\pm \mathrm{SE}$ ) of Mytilus edulis (A: groups of $10 ; n=3$ ), juvenile and adult Magallana gigas (B \& C: groups of 10 or $1 ; n=3$ or 6 , respectively) and Semibalanus balanoides (D: $5 \mathrm{~cm}^{2}$ area with $\geq 80 \%$ cover; $n=3$ ) following exposure to direct steam treatments for up to 300 sec. All species were assessed following a $24-\mathrm{hr}$ recovery period. Shared letters indicate no significant difference $(P>0.05)$.

Figure 2: Mean percentage relative biomass change ( \pm SE) for Fucus vesiculosus (A: $60.5 \pm 0.3 \mathrm{~g} ; n=$ 3 ) and a collection of Ulva sp. (B: $35.3 \pm 0.3 \mathrm{~g} ; n=3$ ) following exposure to direct steam treatments for up to 120 -sec. Mean percentage degradation ( $\pm \mathrm{SE}$ ) for Ulva sp. is also shown (C). Each species was assessed following a 12 or 5 day recovery period, respectively. Shared letters indicate no significant difference $(P>0.05)$. 
Table 1: Study species, source locations, and respective steam treatments.

\begin{tabular}{|c|c|c|c|c|c|}
\hline Species & Common name & Source site & Site name & Steam exposure (sec) & Recovery period (d) \\
\hline Mytilus edulis & Blue mussel & $\begin{array}{l}54^{\circ} 28^{\prime} 05.7^{\prime \prime} \mathrm{N} \\
5^{\circ} 32^{\prime} 20.5^{\prime \prime} \mathrm{W}\end{array}$ & $\begin{array}{c}\text { Horse Island, Strangford } \\
\text { Lough }\end{array}$ & $10,30,60,120,300$ & 1 \\
\hline $\begin{array}{c}\text { Magallana gigas } \\
\text { (Juvenile) }\end{array}$ & Pacific oyster & $\begin{array}{l}49^{\circ} 29^{\prime} 49.0^{\prime \prime} \mathrm{N} \\
2^{\circ} 30^{\prime} 08.2^{\prime \prime} \mathrm{W}\end{array}$ & Guernsey Sea Farms Ltd. & $10,30,60,120,300$ & 1 \\
\hline $\begin{array}{c}\text { Magallana gigas } \\
\text { (Adult) }\end{array}$ & Pacific oyster & $\begin{array}{l}54^{\circ} 14^{\prime} 47.3^{\prime \prime N} \\
5^{\circ} 38^{\prime} 18.5^{\prime \prime} \mathrm{W}\end{array}$ & Killough Oysters Ltd. & $60,120,300$ & 1 \\
\hline $\begin{array}{c}\text { Semibalanus } \\
\text { balanoides }\end{array}$ & Rock barnacle & $\begin{array}{l}54^{\circ} 28^{\prime} 05.7^{\prime \prime} \mathrm{N} \\
5^{\circ} 32^{\prime} 20.5^{\prime \prime} \mathrm{W}\end{array}$ & $\begin{array}{c}\text { Horse Island, Strangford } \\
\text { Lough }\end{array}$ & $10,30,60,120$ & 1 \\
\hline Fucus vesiculosus & Bladder wrack & $\begin{array}{l}54^{\circ} 28^{\prime} 05.7^{\prime \prime} \mathrm{N} \\
5^{\circ} 32^{\prime} 20.5^{\prime \prime} \mathrm{W}\end{array}$ & $\begin{array}{c}\text { Horse Island, Strangford } \\
\text { Lough }\end{array}$ & $10,30,60,120$ & 12 \\
\hline Ulva sp. & $\begin{array}{l}\text { Gut weed/ } \\
\text { Sea lettuce }\end{array}$ & $\begin{array}{l}54^{\circ} 23^{\prime} 32.1^{\prime \prime} \mathrm{N} \\
5^{\circ} 34^{\prime} 28.2^{\prime \prime} \mathrm{W}\end{array}$ & $\begin{array}{l}\text { Ballyhenry Island, } \\
\text { Strangford Lough }\end{array}$ & $10,30,60,120$ & 5 \\
\hline
\end{tabular}



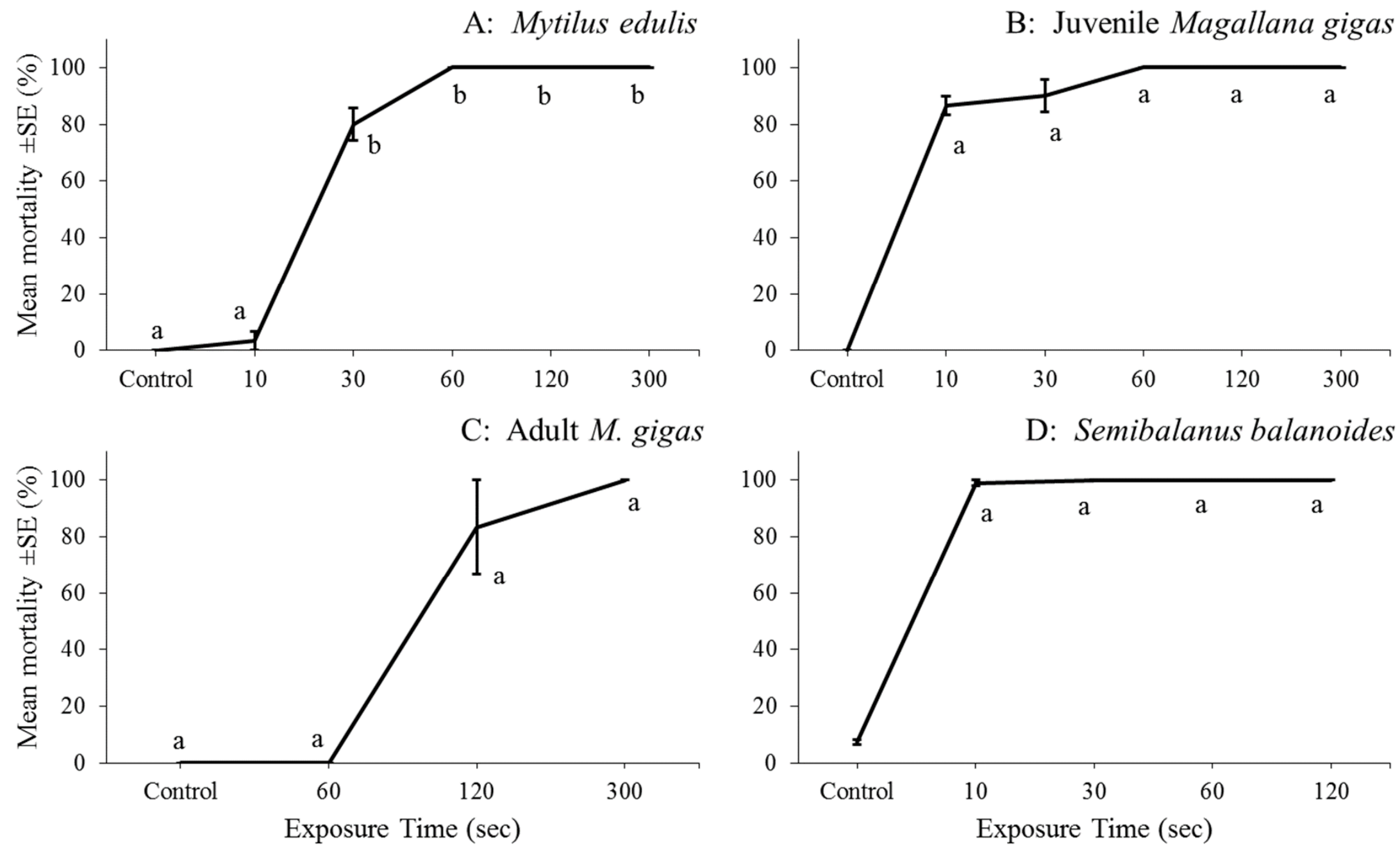
472 Figure 2:
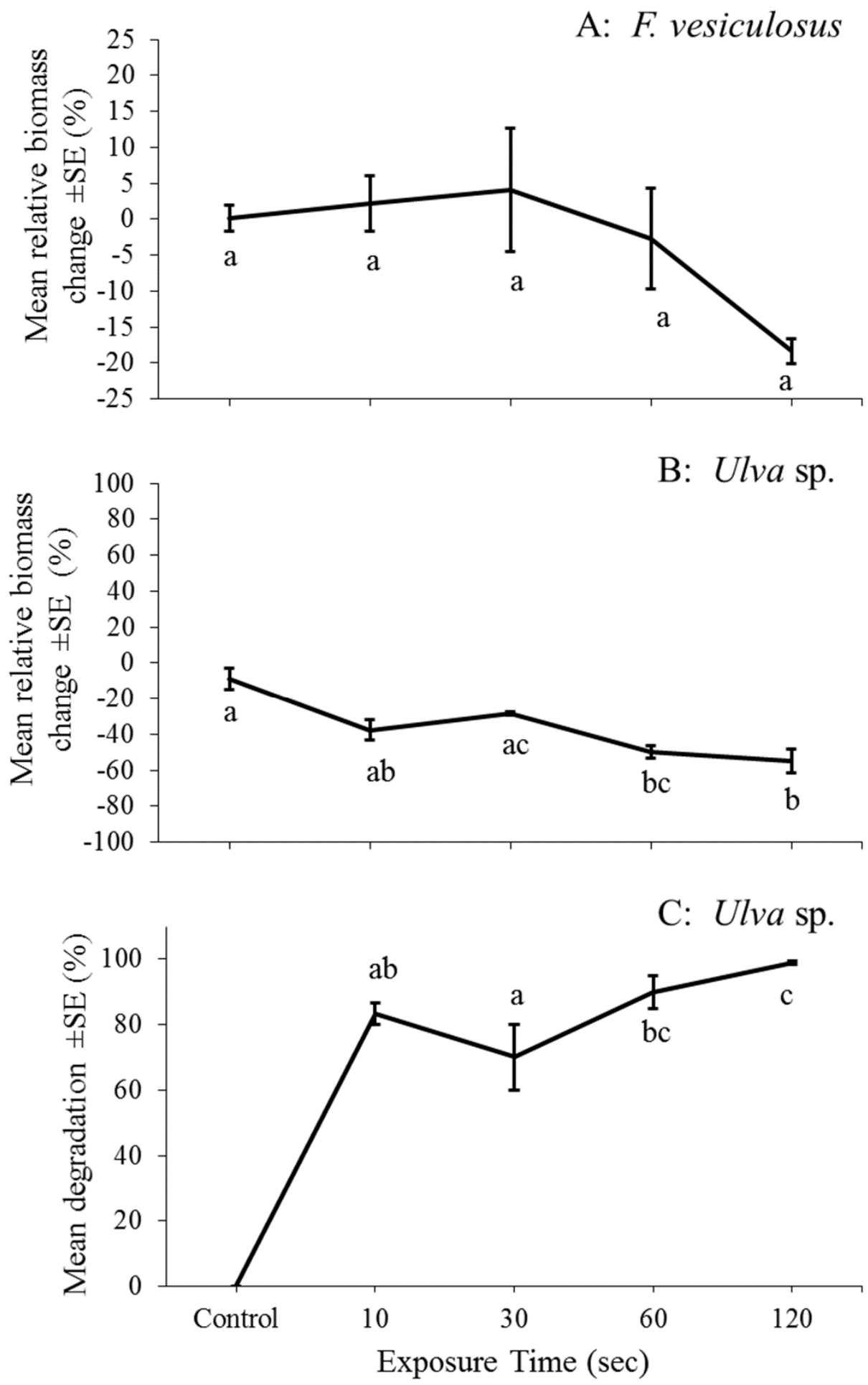